\section{Effects of Different Protocols of Low- Level Laser Therapy on Collagen Deposition in Wound Healing}

John Lennon Silva Cunha ${ }^{1} \oplus$, Felipe Mendes de Andrade de Carvalho ${ }^{1}{ }^{\circledR}$, Rose Nely Pereira Filho ${ }^{1}{ }^{\circ}$, Maria Amália Gonzaga Ribeiro² ${ }^{\circ}$, Ricardo Luiz Cavalcanti de Albuquerque-Júnior ${ }^{1}$ (c)
'Laboratory of Morphology and Experimental Pathology, UNIT - Universidade Tiradentes, Aracaju, SE, Brazil

${ }^{2}$ Department of Dentistry, UFS - Universidade Federal de Sergipe, Aracaju, SE, Brazil

Correspondence: John Lennon Silva Cunha, Avenida Murilo Dantas, 300, 49032-490 Aracaju, SE, Brasil. Tel: +55-79-99654-0805 e-mail: lennonrrr@live.com

\begin{abstract}
The low-level laser has proven successful in stimulating the production of collagen in wound healing assays. However, diversity has been observed in the protocols used. This work has evaluated the effects of three protocols of low-level laser therapy (LLLT) in the healing of open wounds in rats. Standard-sized wounds of $1 \mathrm{~cm}^{2}$ were performed with a scalpel in the middorsal region of 60 male Wistar rats weighing $225 \pm 25 \mathrm{~g}$, and they were assigned into four groups ( $n=15)$ : CTR (non-irradiated animals), LT1 $\left(20 \mathrm{~J} / \mathrm{cm}^{2}\right.$ daily), LT2 $\left(16 \mathrm{~J} / \mathrm{cm}^{2}\right.$ daily) and LT3 (20 J/cm² daily). After 7, 14 and 21 days, five animals/day were euthanized and the wounds analyzed histologically. Data were subjected to normality analysis of distribution using Shapiro-Wilk test. Gaussian data were analyzed using ANOVA and Bonferroni tests whereas non-Gaussian data were analyzed using Kruskal-Wallis and Dunn tests, considering significant $p$ values less than 0.05 . The LLLT in all protocols reduced the inflammation and collagen deposition increased significantly $(p<0.05)$. However, LT2 showed the highest levels of collagen in all phases of the study $(p<0.05)$ induced faster replacement of immature collagen III by mature collagen I in the early stages of repair and early collagen remodeling promoted by providing better organization architectural beams deposited. It was concluded that all protocols induced an increase in collagen scar. However, the protocol $2\left(16 \mathrm{~J} / \mathrm{cm}^{2}\right.$, daily application) promoted the most significant increases in collagen deposition, accelerated maturation of collagen and showed the best architecture of the final fibrous scarring.
\end{abstract}

Key Words: laser therapy, wound healing, collagen.

\section{Introduction}

The wound healing process is a complex pathophysiological process that involves a cascade of coordinated inflammatory and proliferative events $(1,2)$. Wounds with minimal loss of tissue, closed with sutures, tend to heal rapidly. However, chronic wounds, usually with infections, persistence of the inflammatory reaction and intense oxidative stress, exhibit delayed healing (1). The proper care of chronic wounds has become a challenge in public health, often including advanced therapies, such as new drugs and low-level laser therapy (LLLT) (2). Because the pathophysiology of wound healing involves a wide range of biochemical and molecular mechanisms, therapeutic strategies are challenging (3).

LLLT comprises non-invasive and non-ionizing radiation that, in contact with different tissues, promotes thermal, photochemical and non-linear effects (4). It has been reported that LLLT induces fibroblast proliferation and accelerates collagen metabolism. In addition, studies have suggested that LLLT may stimulate healing, promoting increased collagen deposition and accelerating the repair process (5). In addition, the tissue architecture also seems to be influenced by laser irradiation and has been reported in the literature (6-8). Although the precise mechanism of laser photobiomodulation is not completely clear, it has been proposed that LLLT stimulates mitochondrial metabolism, culminating in a greater differentiation and proliferation of fibroblasts and, consequently, a greater deposition of collagen (9).

Previous studies have demonstrated the beneficial effects of LLLT on biosynthesis and collagen metabolism in experimental models of dermal skin injury in rodents $(10,11)$. However, many other controversial data have been reported in the literature on the laser photobiomodulator effect on scar repair, including reduction in collagen synthesis (12-14). This apparent paradox is most likely a result of the variety of parameters used in the experiments, such as energy density and intensity, irradiation time and irradiation mode, for example (15).

The objective of this study was to evaluate the effect of three LLLT protocols using gallium and aluminium arsenide (GaAlAs) diode laser on the scar repair in a murine model.

\section{Material and Methods}

\section{Ethical Aspects}

Ethical principles of the Brazilian College for Animal Experimentation Regulation (CONCEA) were applied in this study, which was approved by the Ethical Committee for 
Animal Experimentation of Tiradentes University (UNIT) (Document approval \#040508).

\section{Biological Assay}

Sixty adult male Wistar rats (Rattus norvegicus albinus) weighing $225 \pm 25 \mathrm{~g}$ were randomly assigned to four experimental groups (Table 1). Animals were housed in plastic cages with bedding of wood-shavings, which was replaced daily, under controlled temperature at $22^{\circ} \mathrm{C}$ and a $12 \mathrm{~h}$ light/dark regimen, with water and food ad libitum (Labina ${ }^{\circledR}$; Purina, São Paulo, Brazil).

\section{Surgical Procedures}

The animals were subjected to dissociative anesthesia with intraperitoneal administration of $0.10 \mathrm{~mL} / 100$ $\mathrm{g}$ of $10 \%$ ketamine (Ketamine ${ }^{\circledR}$, Rhobifarma Ind. Ltd. Pharmaceutical) and $0.25 \mathrm{~mL} / 100 \mathrm{mg}$ of xylazine (Anasedan ${ }^{\circledR}$ Purina). Animals were handled in accordance with the principles of aseptic chain in order to avoid any possibility of exogenous bacterial contamination. Briefly, the animals had their dorse shaved and cleaned with 2\% chlorhexidine solution (Merthiolate ${ }^{\circledR}$, Hypermarcas S.A, Barueri, São Paulo, Brazil) and a standard-sized excisional

Table 1. Distribution of the animals into the 4 groups according to the experimental procedures and irradiation protocol

\begin{tabular}{lcc}
\hline $\begin{array}{c}\text { Groups } \\
(\mathrm{n}=15)^{\mathrm{a}}\end{array}$ & $\begin{array}{c}\text { Light source } \\
\text { type }\end{array}$ & Irradiation protocol \\
\hline CTR $^{\mathrm{b}}$ & - & $0 \mathrm{~J} / \mathrm{cm}^{2 \mathrm{~b}}$ \\
LT1 & GaAlAs laser & $20 \mathrm{~J} / \mathrm{cm}^{2}$ per session, $\lambda 660,40 \mathrm{~mW}, \varnothing=0.04 \mathrm{~cm}^{2}, \mathrm{CW}$ \\
LT2 & GaAlAs laser & $16 \mathrm{~J} / \mathrm{cm}^{2}$ per session, $\lambda 660,40 \mathrm{~mW}, \varnothing=0.04 \mathrm{~cm}^{2}$, CW \\
LT3 & GaAlAs laser & $20 \mathrm{~J} / \mathrm{cm}^{2}$ per session, $\lambda 780,40 \mathrm{~mW}, \varnothing=0.04 \mathrm{~cm}^{2}, \mathrm{CW}$ \\
\hline
\end{tabular}

aEach group is divided in three subgroups $(n=5)$ to be euthanized at 7,14 and 21 days.

${ }^{b}$ The animals were subjected to the same stress conditions of laser therapy.

\section{Low-Level Laser Therapy Procedures}

Laser irradiation was performed using a laser diode GaAlAs (Twin Laser ${ }^{\circledR}$, MMOptics, São Paulo, Brazil) previously calibrated in continuous emission mode. Two different wavelengths were treated; red light (RED; 660 $\mathrm{nm})$, and infrared light (IR; $780 \mathrm{~nm})$. In the experimental groups, the irradiation protocol was started immediately after the wound confection procedure. The animals were irradiated daily for 7 days and euthanized for analysis at 7 days, 14 days and 21 days after injury. Unirradiated animals (control groups) underwent sham irradiation with the laser device unpowered. The irradiation parameters are shown in Table 2.

\section{Histological Procedures}

Five animals of each group were euthanized 7, 14 and 21 days after the surgical procedures in $\mathrm{CO} 2$ chamber (EB 248, $400 \times 320 \times 350$ mm, Insight, São Paulo, SP, Brazil) with $100 \%$ carbon dioxide continuous flux for $5 \mathrm{~min}$. After death certification, the wounded areas were surgically removed (margin of $0.5 \mathrm{~cm}$ ), formalin-fixed and paraffinembedded. Twenty serial 5.0- $\mu \mathrm{m}$-thick histological sections were obtained and stained in hematoxylin/eosin (HE), Sirius red and Masson's trichrome. The histological evaluation was blindly conducted by two examiners previously calibrated.

\section{Assessment of Inflammatory Profile (IP)}

$\mathrm{HE}$-stained sections were used for the descriptive analysis of the inflammatory profile (IP). The intensity of the inflammatory response was classified as follows: 0 (absence of inflammatory response), 1 (inflammatory cells representing less than 10\% of the cell population observed within the wound area), 2 (inflammatory cells representing between $10 \%$ and $50 \%$ of the cell population observed within the wound area), and 3 (inflammatory cells representing more than $50 \%$ of the cell population observed within the wound

Table 2. Experimental groups according to the irradiation protocol with low-level laser therapy

\begin{tabular}{|c|c|c|c|c|c|c|c|c|c|}
\hline $\begin{array}{l}\text { Groups } \\
(n=15)\end{array}$ & $\begin{array}{l}\text { Light } \\
\text { source type }\end{array}$ & $\begin{array}{c}\text { Average } \\
\text { power }(\mathrm{mW})\end{array}$ & $\begin{array}{l}\text { Wavelength } \\
\text { (nm) }\end{array}$ & $\begin{array}{c}\text { Pulse } \\
\text { parameters }\end{array}$ & $\begin{array}{l}\text { Irradiation } \\
\text { points }\end{array}$ & $\begin{array}{c}\text { Applications } \\
\text { per point }\end{array}$ & $\begin{array}{c}\text { Energy } \\
\text { per point } \\
\left(\mathrm{J} / \mathrm{cm}^{2}\right)\end{array}$ & $\begin{array}{c}\text { Total energy } \\
\text { density per } \\
\text { session }\left(\mathrm{J} / \mathrm{cm}^{2}\right)\end{array}$ & $\begin{array}{c}\text { Irradiation } \\
\text { time per } \\
\text { point (s) }\end{array}$ \\
\hline $\mathrm{CTR}^{*}$ & - & - & - & - & & & & & \\
\hline LT1 (18) & $\begin{array}{c}\text { GaAlAs } \\
\text { laser }\end{array}$ & $40 \mathrm{mV}$ & $660 \mathrm{~nm}$ & CW & 4 & 1 & $5 \mathrm{~J} / \mathrm{cm}^{2}$ & $20 \mathrm{~J} / \mathrm{cm}^{2}$ & $30 \mathrm{~s}$ \\
\hline LT2 (7) & $\begin{array}{l}\text { GaAlAs } \\
\text { laser }\end{array}$ & $40 \mathrm{mV}$ & $660 \mathrm{~nm}$ & CW & 4 & 1 & $4 \mathrm{~J} / \mathrm{cm}^{2}$ & $16 \mathrm{~J} / \mathrm{cm}^{2}$ & $30 \mathrm{~s}$ \\
\hline LT3 (17) & $\begin{array}{c}\text { GaAlAs } \\
\text { laser }\end{array}$ & $40 \mathrm{mV}$ & $780 \mathrm{~nm}$ & CW & 4 & 1 & $5 \mathrm{~J} / \mathrm{cm}^{2}$ & $20 \mathrm{~J} / \mathrm{cm}^{2}$ & $25 \mathrm{~s}$ \\
\hline
\end{tabular}

*The animals were subjected to the same stress conditions of laser therapy. 
area). Moreover, the inflammatory profile (IP) was classified as acute (predominance of polymorphonuclear cells) or chronic (predominance of mononuclear cells) and graded as slighter/absent, moderate or severe.

\section{Assessment of Collagen Deposition}

Ten histological sections stained in Sirius red and analyzed under polarized light (100x magnification) were used to the descriptive analysis of the collagen deposition. Collagen fibers were analyzed according to their birefringence pattern (greenish/yellow-greenish or orange I orange-reddish, representing type III and type I collagen fibers, respectively), morphological appearance (wavy or stretched, thin or thick, short or long), and architectural arrangement (reticular, parallel or interlaced arrangement).

\section{Histomorphometric Analysis of Collagens Fibers}

The area occupied by collagen deposition in the wound was quantified by optical density of the image analysis system in eight microscopic fields for each slide with $\times 100$ amplification. The system consists of a CCD Sony DXC-101 video camera applied to an Olympus CX31 microscope, from which the images were sent to a monitor (Sony Trinitron). Through a scanning system (Olympus C-7070 WideZoom), images were loaded into a computer (Pentium $133 \mathrm{MHz}$ ) and processed using the ImageTool software, which provided the interpretation and values corresponding to the measurement of collagen fibers through quantifying their original measures, transforming the measure of the scanned image (pixel) into micrometered measure using a $50-\mu \mathrm{m}$ bar. The thresholds for collagen fibers were established for each blade after increasing the contrast up to a point at which the fibers were easily identified as birefringent (collagen). The area occupied by the fibers was determined by thresholds of the different densities of collagen colors and highlighted by a selection tool.

\section{Statistical Analysis}

Gaussian data were statistically analyzed using twoway analysis of variance followed by multiple comparisons Bonferroni's test. Non-Gaussian data were analyzed using Kruskal-Wallis test followed by multiple comparisons Dunn's test (GraphPad Prism R software, version 6.01; GraphPad Inc., San Diego, CA). The level of significance was set at a $p$ value less than 0.05 .

\section{Results}

\section{Analysis of the inflammatory profile (IP)}

At 7 days, the IP was significantly more intense in the CTR group than in the LT3 $(p<0.05)$ group, but no significant difference was evident among the other groups. At 14th and 21 days, the IP was significantly more intense in the
CTR group than in the LT1 $(p<0.05)$, LT2 $(p<0.05)$ and LT3 $(p<0.05)$, but no other significant difference was evident among the irradiated groups (Table 3 ).

At 7 days, the $\mathrm{HE}$-stained sections presented exuberant granulation reaction was observed in the four experimental groups, with the formation of slit capillary vessels supported by a delicate eosinophilic fibrillar network. At 14 days, only in the CTR group was observed the persistence of a moderate chronic inflammatory reaction (lymphocytic), concentrated on the surface of the wound. In the other groups, the inflammation was mild and the remaining capillaries were sparsely distributed and immersed in a network of thicker eosinophilic bundles. At 21 days, only CTR showed mild and occasional infiltration of lymphocytes, in contrast to the non-inflamed collagenous scar of the other groups (Fig. 1).

\section{Morphological Analysis of Collagenization}

Analysis of histological sections under polarized light (Fig. 2) revealed, in 7 days, the deposition of thin and short fibrils of type III collagen (with greenish birefringence)

Table 3. Severity of the inflammatory infiltrate in the groups at 8th, 14 th and 21 days

\begin{tabular}{|c|c|c|c|c|c|}
\hline \multirow{2}{*}{ Time } & \multirow{2}{*}{ Animals } & \multicolumn{4}{|c|}{ Groups } \\
\hline & & CTR & LT1 & LT2 & LT3 \\
\hline \multirow{5}{*}{8 days } & $\mathrm{R} 1$ & 3 & 3 & 3 & 2 \\
\hline & $\mathrm{R} 2$ & 3 & 3 & 2 & 2 \\
\hline & R3 & 3 & 2 & 3 & 2 \\
\hline & R4 & 3 & 2 & 2 & 2 \\
\hline & R5 & 3 & 3 & 2 & 2 \\
\hline \multirow{5}{*}{14 days } & R1 & 1 & 1 & 1 & 0 \\
\hline & R2 & 1 & 1 & 1 & 1 \\
\hline & R3 & 0 & 0 & 0 & 0 \\
\hline & R4 & 1 & 1 & 1 & 1 \\
\hline & R5 & 0 & 0 & 0 & 0 \\
\hline \multirow{5}{*}{21 days } & R1 & 1 & 0 & 0 & 0 \\
\hline & $\mathrm{R} 2$ & 0 & 0 & 0 & 0 \\
\hline & R3 & 1 & 0 & 0 & 0 \\
\hline & R4 & 1 & 0 & 0 & 0 \\
\hline & R5 & 0 & 0 & 0 & 0 \\
\hline
\end{tabular}

$0=$ inflammatory infiltrate is absent; $1=$ mild inflammatory infiltrate corresponding to less than $10 \%$ of stromal cells; $2=$ moderate inflammatory infiltrate corresponding to more than 10 and less than $50 \%$ of stromal cells; $3=$ intense inflammatory infiltrate corresponding to more than 50\% of stromal cells. R1-R5: Animals for each experimental group ( 5 animals/group). 
in a predominantly reticular arrangement in CTR and LT1. The fibrils, however, were poorly evident, and the interfibrillar spaces were abundant. In LT2 and LT3, it was possible to show more fibrillation condensation in the wound depth, as well as the deposition of some fibrils with a yellow-golden birefringence (type I collagen). In 14 days, the deposition of type I collagen was predominant in all groups, parallel to the surface. However, in LT2, the deposition of thick bundles with coarse appearance and an interlaced arrangement was observed in some areas of the specimen. In all groups, the interfibrillar spaces were greatly reduced. In 21 days, CTR and LT1 presented similar patterns of collagen deposition, with a predominance of type I collagen fibers. These were thinner and more delicate, with a parallel arrangement on the surface of the specimens, but thick, coarse and intertwined in the depth. It should be noted, however, that in LT1, but not in CTR, bundles with reddish birefringence, typical of mature type I collagen, were observed. LT2 and LT3, in turn, exhibited deposition of very thick and interlaced collagen bundles, filling the wound area completely, with scarce interfiber spaces. However, the deposited fiber pattern was patently distinct, since these were predominantly type I in LT3, whereas in $\Xi$ LT2 there was a clear mixture of type I and more delicate type III thick bundles.

At 7 days, the collagen fibers evidenced by Masson's
Trichrome were shown to be quite scarce in the CTR group and more visible in the irradiated groups, particularly in LT2. At 14 days, they were well marked and parallelly arranged in the three irradiated groups, but still paleness stained in CTR, suggesting less collagenous condensation. At 21 days, the bundles are thick, coarse and intertwined at the base of the wound and thin, delicate and parallel at the surface in CTR and LT1. On the other hand, in LT2 and LT3, homogeneous deposition of thick, coarse and interlaced bundles was observed throughout the cicatricial area (Fig. 3).

\section{Quantitative analysis of the collagenization rate (CR)}

The quantitative analysis of the collagen fibers stained by Masson's Trichrome (Fig. 4) revealed that in seven days the LT2 group presented significantly more intense deposition than the other groups $(p<0.05)$, but there was no difference between the other groups ( $p>0.05)$. At 14 days, all the irradiated groups showed higher collagenization than the control group $(p<0.05)$; in addition, the LT2 group showed significantly higher rates of collagen deposition than the other irradiated groups $(p<0.05)$, but there was no difference between LT1 and LT3 ( $p>0.05)$. In 21 days, all irradiated groups were more collagenated than the CTR group ( $<<0.05)$. In addition, LT2 and LT3 presented statistically similar percentages of collagenization $(p>0.05)$, both higher than in LT1 $(p<0.05)$.
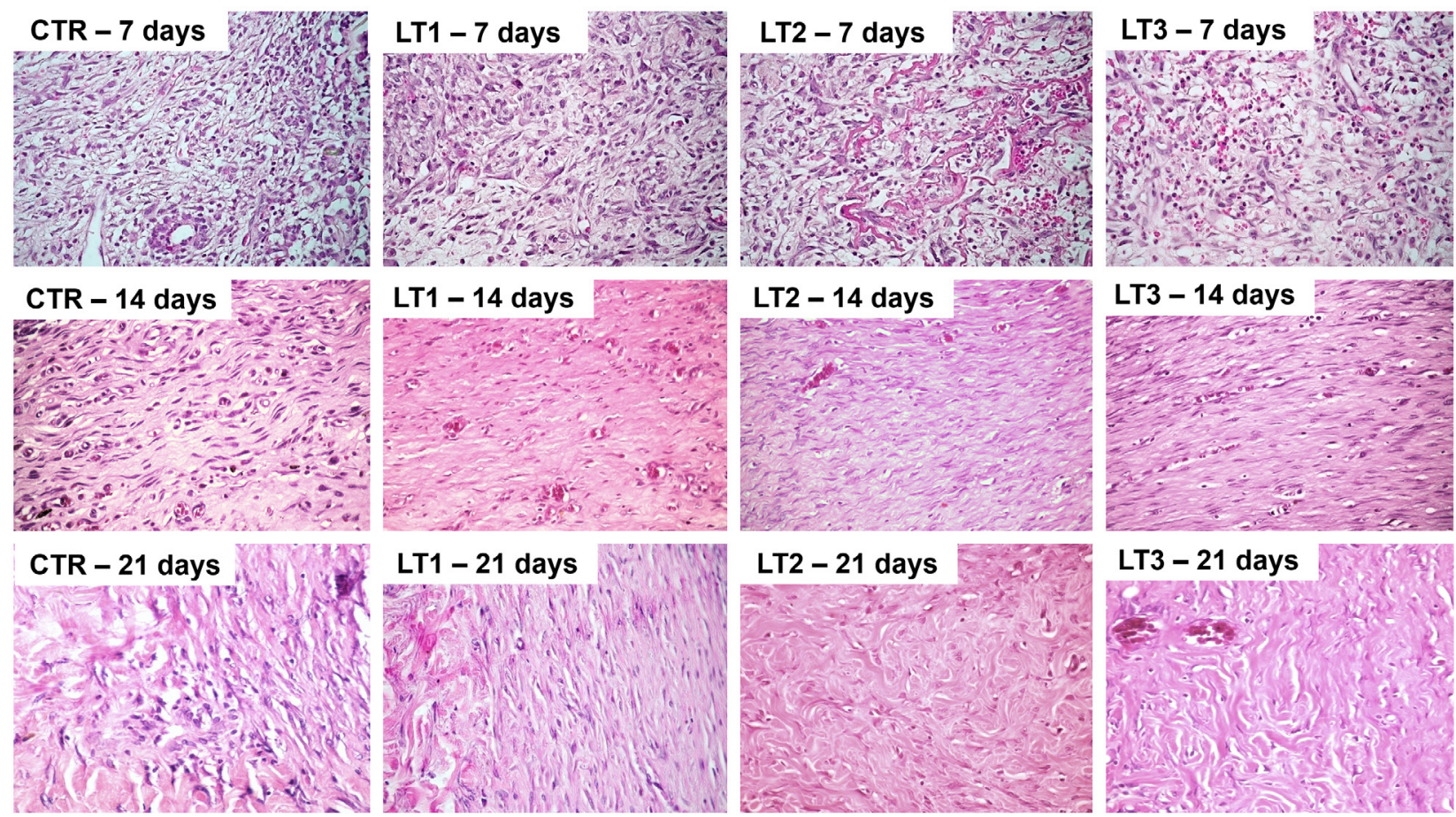

Figure 1. Histological findings observed in the experimental groups during the time-course of the study. In seven days, exuberant granulation reaction characterized by proliferation of fibroblasts and new thin-walled, delicate capillaries (angiogenesis), infiltrated inflammatory cells in a loose extracellular matrix was observed in all groups; at 14 days, a residual granulation reaction in CTR is evident, but not in the irradiated groups. At 21, days dense fibrous scarring occurs, with parallel beams in CTR and LT1, but densely intertwined in LT2 and LT3 (HE, 100x). 

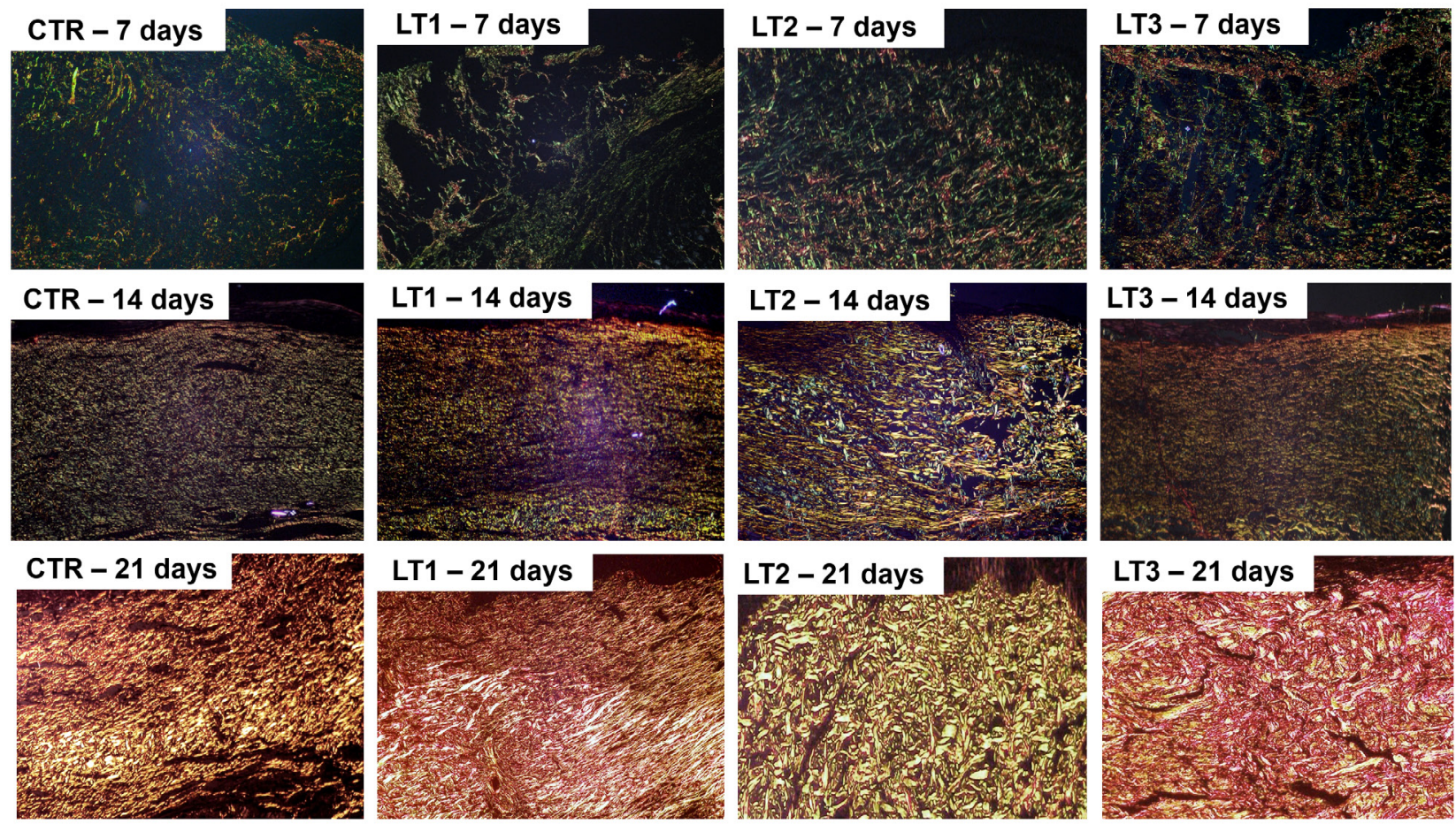

Figure 2. Collagen deposition in the experimental groups during the time-course of the study. At 7 days, there is deposition of scarce and thin type III collagen fibrils organized in a reticular pattern. Higher densification of fibrils in LT2 and LT3. In 14 days, deposition of thin fibers of type I collagen, with a parallel arrangement in CTR, LT1, and LT3, but lightly interlaced in LT2, is observed. At 21 days, there is a predominance of coarse bundles of type I collagen, with a higher density in the depth of the specimen in CTR and LT1 (observe bundles with reddish birefringence in the latter group, indicating more mature collagen). In LT2 and LT3, collagen deposition was quite dense and intertwined; observed a mixture of collagen bundles type I and III in LT2, while in LT3 type I collagen was clearly more abundant (Sirius Red/Polarization Light, 200×).
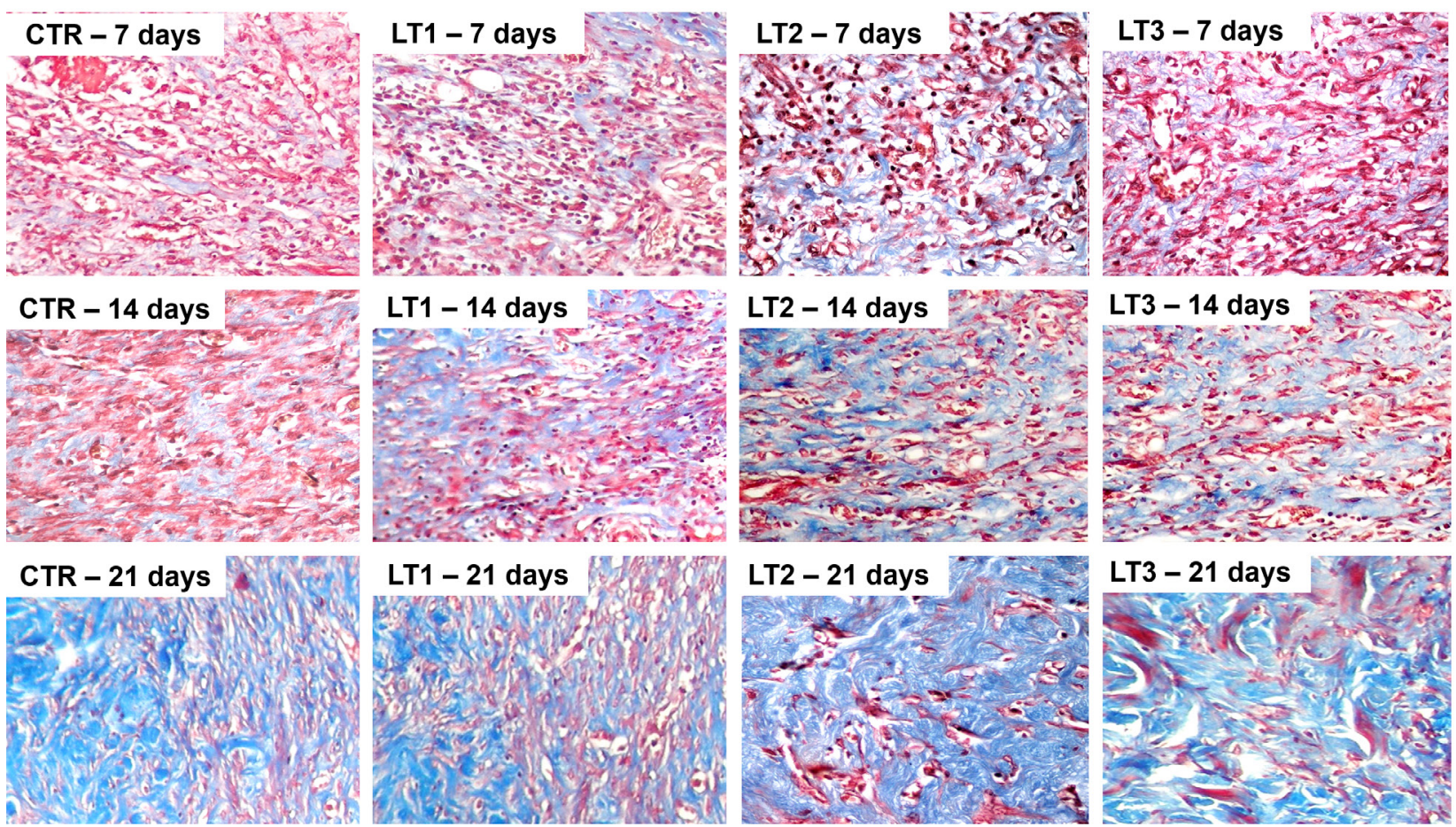

Figure 3. Delicate collagen fibers highlighted in blue paleness stained at 7 days. at 14 days, the collagen bundles are more visible and have a parallel arrangement. Note that in the CTR group, the fibers are less marked than the others. At 21 days, the beams are predominantly thick, coarse and interlaced, particularly in LT2 and LT3 (Masson's trichrome, 200x). 


\section{Discussion}

Low-level laser therapy provided a significant decrease in the severity of the inflammatory response in the late phases of wound healing independent of the protocol used. Supporting our findings, similar results have also been reported in the literature (15-17).

In the current study, LLLT reduced the magnitude of the inflammatory response. Supporting these data, Ribeiro et al. (18) have demonstrated that laser irradiation stimulates the proliferation of lymphocytes, accelerating the chronification of inflammation, a crucial event for scar repair to occur. Paradoxically, Pereira et al. (19) have observed that LLLT in the red spectrum promotes a significant increase in mast cell degranulation in the first $24 \mathrm{~h}$ after tissue aggression, generating a transient amplification of the acute inflammatory response, followed by a substantial reduction in neutrophil content after $36 \mathrm{~h}$. These data seem to suggest that LLLT modulates the inflammatory response in order to accelerate the acute phase and thus culminate in the anticipation of process chronification. Although the precise mechanisms underlying the modulatory effects of LLLT on the inflammatory response were not investigated in the current paper, it is possible to suggest that it might be related to the inhibitory effect of laser energy on the release of pro-inflammatory chemical mediators, such as TNF- $\alpha$, IL-1 $\beta$ and IL-6, as previously described (15). However, further investigations are still necessary to attest this hypothesis.

In the present study, a progressive increase in the density of scarring collagen was observed throughout the three periods analyzed. In addition, all LLLT protocols determined an increment in the deposition of collagen fibers in the three experimental phases. The modulatory activity of LLLT on collagenization during scar repair has been exhaustively studied in the literature $(5-7,14,17,18,20)$. Tila Fortuna et al. (5) also observed a significant increase in the deposition of collagen fibers in irradiated wounds, while Nayak et al. (20) demonstrated an increase in the content of hydroxyproline, a marker of collagen formation. Such increased collagenization might be likely a result of
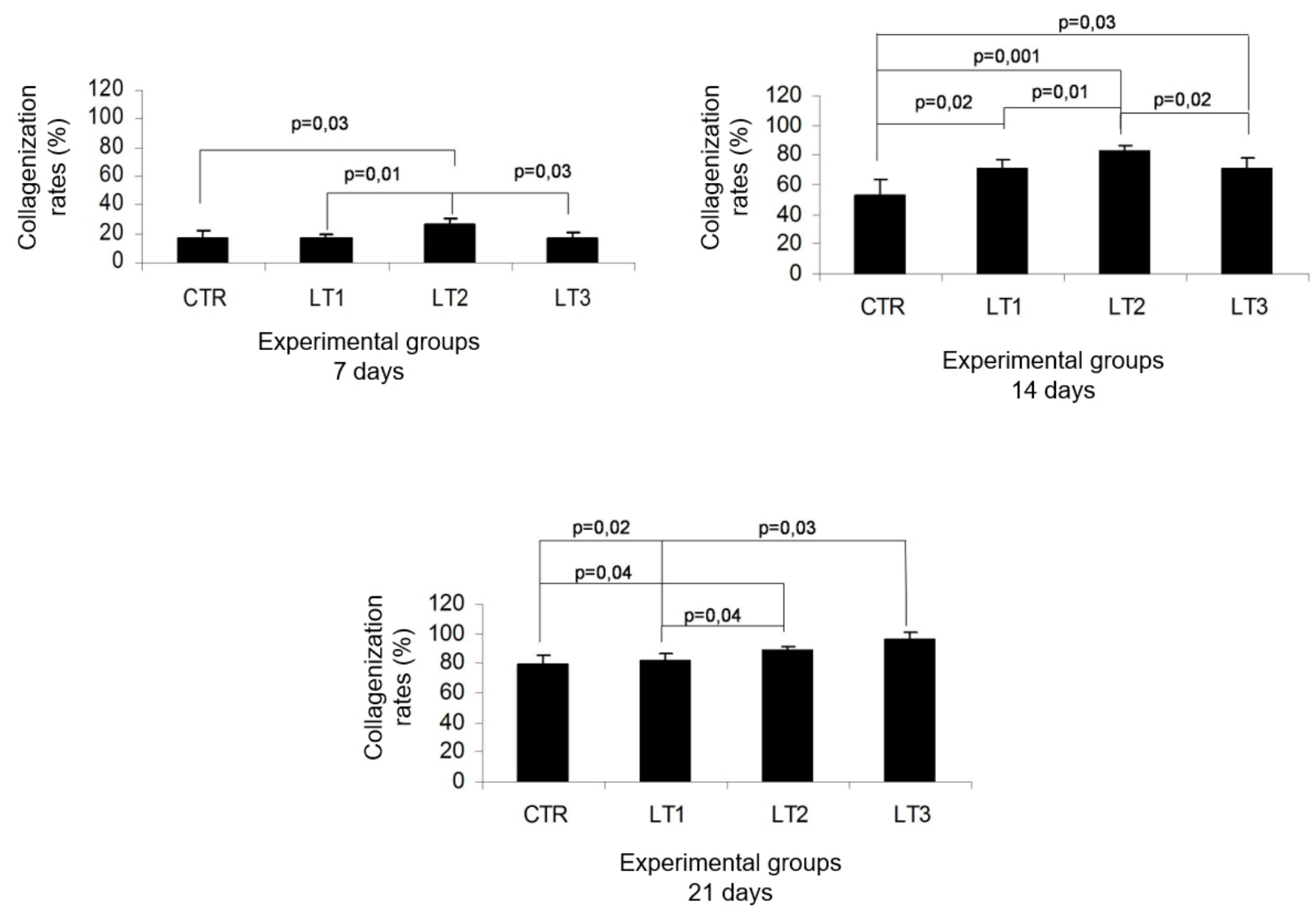

Figure 4. Collagenization rates of the wounds At 7, 14 and 21 days. 
the modulatory activity of the laser light at the subcellular level, promoting proliferation and increase of the protein synthesis in the irradiated cells. The precise mechanism underling this biological activity is still under investigation. However, a possible role played by intracellular chromophores, such as porphyrins and cytochromes, which are capable of absorbing light energy and converting it into metabolic energy, has been suggested. Thus, LLLT would be able to improve scar repair by direct stimulation of fibroblastic metabolism, promoting an enhancement of the in intracellular levels of adenosine triphosphate and consequently increased protein synthesis, particularly collagen (16). In addition, LLLT promotes important changes in the chemical mediators directly involved in repair, such as reduction of cyclooxygenase-2 (COX-2) expression and consequently the severity of the inflammatory response and increased expression of VEGF, a crucial growth factor for formation of granulation tissue $(15,21)$.

The LT2 protocol $\left(16 \mathrm{~J} / \mathrm{cm}^{2}\right.$, daily) promoted the highest rates of collagen deposition over time, suggesting that the daily application of LLLT induced a more intense stimulation effect on fibroblastic activity. Surprisingly, it has been reported that the application of this dosimetry promoted inhibition of collagen deposition (12). This apparent paradox can be explained by the fact that the laser used in this study used HeNe (helium and neon) as an active medium, in contrast to GaAlAs used in the present study. In addition, the difference in frequency of applications could have determined different effects on irradiated target cells.

During wound healing, type III collagen is first synthesized and deposited allowing the endothelial cells to migrate to form the network of capillaries typically seen in the granulation tissue in the early stages of scar repair. Subsequently, type III collagen is progressively replaced by thicker, more resistant and densely organized Type I collagen fibers (22). Thus, increasing the type I/III collagen relation over the time-course of wound healing is required to provide tensile strength and mechanical stability to the fibrous scar (23).

Based on the morphological analysis under polarized light of the histological sections stained by Sirius red, as well as the evaluation of the type I/III collagen ratio, it was verified that all the LLLT protocols tested promoted acceleration in the deposition pattern and improvement in the morphoarchitecture of deposited collagen fibers. However, the pattern of collagen formation observed in LT2 presented unique characteristics, such as earlier replacement of type III collagen molecules by type-I fibers and faster interweaving of the deposited fibers. This interwoven arrangement of the type-I collagen bundles represents an important step of the cicatricial remodeling, providing greater resistance to the repaired tissue, since it allows the dispersion of mechanical energy in several directions (12). Similar patterns of collagenization have also been observed in other experimental studies analyzing the cicatricial process in rodent model $(5-7,17,24)$. In addition, at 21 days, only the LT2 group demonstrated the neoformation of collagen III fibrils interspersed with the collagen I bundles. These data seem to suggest an acceleration in the remodeling process of the fibrous scar (25), so that the repaired dermal tissue resembled the pattern evidenced in normal skin.

The orientation of the collagen fibers was also found to be predominantly reticular on day 7 , irrespective to the LLLT protocol applied in the current study. This pattern of collagen deposition provides a framework through which endothelial cells migrate to form the network of capillaries typically seen in granulation tissue (26). On day 14 and 21 , the arrangement of the collagen fibers was looser and parallel on the surface, but denser and interlaced at the bottom. This bimodal pattern of collagen deposition appears to be an attempt to imitate the original structure of the dermal connective tissue, since collagenization in the superficial papillary dermis is less dense and tends to have a parallel arrangement as opposed to the more dense and interlaced arrangement of collagen in the deeper reticular dermis (27).

Taken together, these data seem to support the theory that LLLT plays an important biomodulatory role in the dynamics of inflammatory response, fibroblast activity and collagen synthesis.

In conclusion, in all protocols LLLT reduced inflammation and significantly increased collagen deposition, showing that all protocols used promoted important alterations in the dynamics of cicatricial fibrogenesis. However, the LT2 protocol $\left(16 \mathrm{~J} / \mathrm{cm}^{2}\right.$, daily application) determined better collagenization indexes such as: more significant increase in collagen deposition, acceleration in the replacement of collagen I molecules by III and promoted early collagen remodeling, presenting better morpho-architectural organization of final fibrous scar.

\section{Resumo}

0 laser de baixa potência provou ter sucesso em estimular a produção de colágeno em ensaios de cicatrização de feridas. Entretanto, grande diversidade tem sido observada nos protocolos utilizados. Este trabalho avaliou os efeitos de três protocolos de Terapia a Laser de Baixa Potência (TLBP) na cicatrização de feridas abertas em ratos. Feridas padronizadas com $1 \mathrm{~cm}^{2}$ de tamanho foram realizadas com um bisturi na região do dorso de 60 ratos Wistar machos pesando $225 \pm 25 \mathrm{~g}$, e foram divididos em quatro grupos ( $n=15)$ : CTR (animais não irradiados), LT1 (20 J/cm² diariamente), LT2 (16 J/cm² diariamente) e LT3 (20 J/ $\mathrm{cm}^{2}$ diariamente). Após 7, $14 \mathrm{e}$ 21 dias, cinco animais/dia foram eutanasiados e as feridas analisadas histologicamente. Os dados foram submetidos à análise de normalidade da distribuição pelo teste de Shapiro-Wilk. Os dados gaussianos foram analisados pelos testes ANOVA e Bonferroni, enquanto que os dados não Gaussianos foram analisados pelos testes de Kruskal-Wallis e Dunn, 
considerando-se valores p significativos menores que 0,05. A TLBP em todos os protocolos reduziu a inflamação e aumentou significativamente a deposição de colágeno $(p<0,05)$. Entretanto, LT2 apresentou os maiores niveis de colágeno em todas as fases do estudo $(p<0,05)$, induzindo a substituição mais rápida do colágeno imaturo III pelo colágeno maduro I nos estágios iniciais de reparo e remodelação precoce do colágeno promovida por melhor organização dos feixes depositados. Concluiu-se que todos os protocolos induziram aumento da cicatriz de colágeno. Entretanto, o protocolo $2\left(16 \mathrm{~J} / \mathrm{cm}^{2}\right.$, aplicação diária) promoveu os aumentos mais significativos na deposição de colágeno, acelerou a maturação do colágeno e apresentou a melhor arquitetura da cicatriz fibrosa final.

\section{Acknowledgements}

We would like to thank the National Council for Scientific and Technological Development (CNPQ) for financial support.

\section{References}

1. Iqbal A, Jan A, Wajid MA, Tariq S. Management of Chronic Non-healing Wounds by Hirudotherapy. World J Plast Surg 2017;6:9-17.

2. Das $S$, Baker $A B$. Biomaterials and Nano therapeutics for Enhancing Skin Wound Healing. Front Bioeng Biotechnol 2016;31;4:82.

3. Pang C, Ibrahim A, Bulstrode NW, Ferretti P. An overview of the therapeutic potential of regenerative medicine in cutaneous wound healing. Int Wound J 2017;14:450-459.

4. Prindeze NJ, Moffatt LT, Shupp JW. Mechanisms of action for light therapy: a review of molecular interactions. Exp Biol Med (Maywood) 2012;237:1241-1248.

5. Fortuna T, Gonzalez AC, Sá MF, Andrade ZA, Reis SRA, Medrado ARAP. Effect of $670 \mathrm{~nm}$ laser photobiomodulation on vascular density and fibroplasia in late stages of tissue repair. Int Wound J 2018;15:274-282.

6. Pugliese LS, Medrado AP, Reis SR, Andrade ZA. The influence of lowlevel laser therapy on biomodulation of collagen and elastic fibers. Pesqui Odontol Bras 2003;17:307-313.

7. Gonzaga Ribeiro MA, Cavalcanti de Albuquerque RL, Santos Barreto AL, Moreno de Oliveira VG, Santos TB, Freitas Dantas CD. Morphological analysis of second-intention wound healing in rats submitted to $16 \mathrm{~J} /$ $\mathrm{cm}^{2} \lambda 660-\mathrm{nm}$ laser irradiation. Indian J Dent Res 2009;20:390.

8. Alves AN, Fernandes KP, Melo CA, Yamaguchi RY, França CM, Teixeira $D F$, et al. Modulating effect of of low level-laser therapy on fibrosis in the repair process of the tibialis anterior muscle in rats. Lasers Med Sci 2014;29:813-821.

9. De Freitas LF, Hamblin MR. Proposed mechanisms of photobiomodulation or low-level light therapy. IEEE J Sel Top Quantum Electron 2016;22:7000417.

10. Baptista J, Martins MD, Pavesi VC, Bussadori SK, Fernandes KP, Pinto Júnior Ddos $\mathrm{S}$, et al. Influence of laser photobiomodulation on collagen IV during skeletal muscle tissue remodeling after injury in rats. Photomed Laser Surg 2011;29:11-17.

11. Martignago CC, Oliveira RF, Pires-Oliveira DA, Oliveira PD, Pacheco Soares C, Monzani PS, et al. Effect of low-level laser therapy on the gene expression of collagen and vascular endothelial growth factor in a culture of fibroblast cells in mice. Lasers Med Sci 2015;30:203-208.

12. Hawkins $\mathrm{DH}$, Abrahamse $\mathrm{H}$. The role of laser fluence in cell viability, proliferation, and membrane integrity of wounded human skin fibroblasts following helium-neon laser irradiation. Lasers Surg Med 2006;38:74-83.
13. Assis L, Moretti Al, Abrahão TB, de Souza HP, Hamblin MR, Parizotto NA. Low-level laser therapy $(808 \mathrm{~nm})$ contributes to muscle regeneration and prevents fibrosis in rat tibialis anterior muscle after cryolesion. Lasers Med Sci 2013;28:947-955.

14. de Freitas $C E$, Bertaglia RS, Vechetti Júnior IJ, Mareco EA, Salomão RA, de Paula TG, et al. High Final Energy of Low-Level Gallium Arsenide Laser Therapy Enhances Skeletal Muscle Recovery without a Positive Effect on Collagen Remodeling. Photochem Photobiol 2015;91:957965.

15. Nascimento MF, Almeida BM, Cunha JL, Valois RB, Pinheiro JC, Ribeiro $M A$, et al. Improvement of bone repair in diabetic rats subjected to $\lambda 780 \mathrm{~nm}$ low-level laser therapy. Acta Cir Bras. 2015;30:660-667.

16. Marinho RR, Matos RM, Santos JS, Ribeiro MA, Ribeiro RA, Lima RC Jr, et al. Potential anti-inflammatory effect of low-level laser therapy on the experimental reflux laryngitis: a preliminary study. Lasers Med Sci 2014;29:239-243.

17. Dantas $M D$, Cavalcante $D R$, Araújo $F E$, Barretto $S R$, Aciole GT, Pinheiro $\mathrm{AL}$, et al. Improvement of dermal burn healing by combining sodium alginate/chitosan-based films and low level laser therapy. J Photochem Photobiol B 2011;105:51-59.

18. Ribeiro MA, Albuquerque RL Jr, Ramalho LM, Pinheiro AL, Bonjardim LR, Da Cunha SS. Immunohistochemical assessment of myofibroblasts and lymphoid cells during wound healing in rats subjected to laser photobiomodulation at $660 \mathrm{~nm}$. Photomed Laser Surg 2009;27:49-55.

19. Pereira $M C$, de Pinho $C B$, Medrado AR, Andrade ZA, Reis SR. Influence of $670 \mathrm{~nm}$ low-level laser therapy on mast cells and vascular response of cutaneous injuries. J Photochem Photobiol B 2010;98:188-192.

20. Nayak BS, Maiya A, Kumar P. Influence of Helium-Neon laser photostimulation on excision wound healing in Wistar rats. Online J Biol Sci 2007;7:89-92.

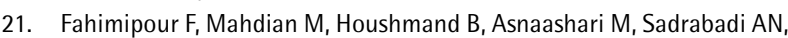
Farashah SE, et al. The effect of He-Ne and Ga-Al-As laser light on the healing of hard palate mucosa of mice. Lasers Med Sci 2013;28:93-100.

22. Fleischmajer R, Perlish JS, Burgeson RE, Shaikh-Bahai F, Timpl R.Type I and type III collagen interactions during fibrillogenesis. Ann N Y Acad Sci 1990;580:161-175.

23. Martini CA, Scapini JG, Collaço LM, Matsubara A, Veiga Júnior VF. Comparative analysis of the effects of Copaifera multijuga oil-resin and nitrofurazona in the cutaneous wound healing process. Rev Col Bras Cir 2016;43:445-451.

24. Medrado AP, Soares AP, Santos ET, Reis SR, Andrade ZA. Influence of laser J photobiomodulation upon connective tissue remodeling during wound healing. Photochem Photobiol B 2008;92:144-152.

25. Silveira PC, Silva LA, Freitas TP, Latini A, Pinho RA. Effects of lowpower laser irradiation (LPLI) at different wavelengths and doses on oxidative stress and fibrogenesis parameters in an animal model of wound healing. Lasers Med Sci 2011;26:125-131.

26. Barreto RS, Albuquerque-Júnior RL, Araújo $A A$, Almeida JR, Santos MR, Barreto AS, et al. A systematic review of the wound-healing effects of monoterpenes and iridoid derivatives. Molecules 2014;19:846-862.

27. Junqueira LC, Montes GS, Martins JE, Joazeiro PP. Dermal collagen distribution. A histochemical and ultrastructural study. Histochemistry 1983:79:397-403.
Received July 24, 2018

Accepted January 15, 2019 